\title{
Who Protects Workers in a Neoliberal State? Estonian Employers and Trade Unionists' Conflicting Views on Labour Relations
}

\author{
By Kairit Kall ${ }^{*}$
}

Taking Estonia as an example, this paper analyses discourses on labour relations by the representatives of employers' associations and trade union federations in a contemporary neoliberal labour market a few years after the financial and economic crises of 2008. Estonia has been classified as an example of a neoliberal market economy where, on the one hand, social security benefits are quite limited and, on the other hand, the position of trade unions in shaping labour relations in companies or at sector level and influencing public policies has also been rather weak). These aspects raise a question: Who protects workers' interests in a neoliberal state (like Estonia)? This paper analyses how the abovementioned labour market counterparties perceive labour relations in general and the role of trade unions in particular. In doing so, the paper contributes to understanding how the need for employee representation and protection is nowadays evaluated. The analysis is based on 15 semi-structured individual and group interviews with nine representatives of Estonian employers' associations and 14 representatives of trade unions federations conducted in 2011. The results highlight a rather similar understanding within one group (employers versus employees) and a controversial one between these two groups regarding the necessity of a collective representation of employees.

Keywords: Employers' organizations, Estonia, Labour relations, Neoliberalism, Trade unions.

\section{Introduction}

Precarious jobs and declining labour standards have become an important issue in Europe, especially related to the economic downturn of 2008 (e.g. Standing 2011). Trade union revitalisation is a tactic offered to tackle these trends (Turner 2005). This paper analyses how employees' representation and protection, and the role of unions in general, is perceived in Estonia's neoliberal post-socialist labour market. Specifically, the discourses on the labour relations of two labour market counterparties - representatives of employers' associations and trade union federations - are examined, a few years after the financial and economic crises of 2008.

* PhD Candidate, Tallinn University, Estonia and University of Jyväskylä, Finland. 
Unlike Western Europe, trade unions in Central and Eastern European (CEE) countries haven't had much real influence in shaping labour related policies. Although several tripartite institutions (that include the representatives of employers, trade unions and the state) were created after the CEE countries gained independence, it has been argued that these only provide a facade under which neoliberal policies are adopted (Ost 2000). In accordance with Ost's (2000) "illusory corporatism" argument, Woolfson and Kallaste (2011) show that although formally trade union and employers' representatives may be involved in shaping labour related policies in Estonia, in reality the government still dominates and can withdraw from tripartite agreements "if needed".

Compared to the other CEE countries, Estonia, since regaining its independence in 1991, has undergone a somewhat radical transformation. Feldmann and Sally (2002:79) even note that this was "the most comprehensive transformation of a national economy in modern times". This radical transformation has had considerable influence on the position of trade unions. Notably, trade union density has dropped significantly since the beginning of the 1990s, such that nowadays Estonia has among the lowest union density rates and collective agreement coverage in Europe (Visser 2013).

In this paper, I draw on the macro-level analyses about the varieties of capitalism in Central and Eastern Europe (e.g. Bohle and Greskovits 2007, 2012, Feldmann 2006) and the critical discourse analysis (Fairclough 1993). Linking these two approaches enables the connection of micro and macro levels in a manner that has not been sufficiently elaborated in the literature dealing with labour relations in CEE countries. Mrozowicki, Pulignano and Hootegem (2010: 222) note that deductive structuralist and culturalist approaches have dominated explanations of unionism's in the CEE countries. Using data, based on interviews with both trade union and employers' representatives - examined from the critical discourse analyses perspective this paper links micro level discourses to the wider societal context. This approach enables to look for a possible variety of ideas, both conflicting with and in accordance with dominant discourses.

\section{Estonian Labour Relations in Comparative Perspective}

In order to understand Estonia's unique labour relations, a brief discussion of the labour relations in Central and Eastern Europe generally, - with some comparison to Western Europe - is in order. Firstly, the conception of historical legacies is introduced. Secondly, the dominance of neoliberal logic in contemporary societies is highlighted. Lastly, a short overview is given about Estonia's background and its current situation regarding labour relations.

\section{Legacies and Path Dependence}

Legacies of the past are a central concept that several authors (e.g. Bohle and Greskovits 2007, Crowley 2004, Feldmann 2006, Ost 2009) have used to explain the specificity of CEE countries' industrial relations systems and the 
position (mostly of weakness) of trade unions. Crowley (2004: 420) states that the legacy of communist past is particularly noticeable when it comes to trade unions, because the old regime claimed to rule on behalf of the working class. In the former communist block trade unions actually did not have any real power to influence processes that regulated workers' rights (Kubicek 2002: 607). At the same time when talking about communist / Soviet past legacies, researchers also emphasize different (although interrelated) aspects, like dominant cultural discourses (Ost 2009), institutional heritage (Feldmann 2006) or workers identity construction (Frege 2001).

Bohle and Greskovits (2007: 462) stress that "the legacies of the past, and their perceptions by the reform elites, as either threats or assets for their countries' future, had a deep impact on regime types", including industrial relation systems, that developed in Central and Eastern Europe during the postsocialist period. The range of capitalist forms displayed some diversity, with a neoliberal type in the Baltic States (Estonia, Latvia and Lithuania), an embedded neoliberal type in the Visegrád states (the Czech Republic, Hungary, Poland and Slovakia), and a neo-corporatist type in Slovenia. They add (ibid.) that the Baltic countries could neither take state institutions nor their nation state for granted, and instead had to start "from scratch". Also, state-socialism persisted longer than in the other CEE countries.

According to Ost (2009) the anti-labour tendencies that were dominant in Central and Eastern Europe after the restoration of independence have influenced the way industrial relations are currently perceived. He argues that although post-communism may have formally ended, there still exists the ideological legacies of post-communism, among these a general distrust of the unions who are associated with the old regime and who are perceived as inadequate, ineffective and unnecessary organizations (ibid.).

\section{Social Compromise and Neo-liberalism}

In Western-Europe, trade unions historically have had significant influence over the development of a so-called European social model; the underlying idea of which being a social/historical compromise between capital and labour (Bohle and Greskovits 2004: 2, Cradden 2011: 50). Nonetheless, the last decades have seen the trade union movement all over the world experience pressures that arguably have changed and weakened their position. Notable among these pressures are the globalization process, with intensified global competition, increased mobility of workers and companies, diversified forms of employment (like short-term and casual employment, self-employment), rising unemployment, sectoral shifts and the like (Calmfors et al. 2001). Additionally, the necessity of a social compromise, that has underpinned the European social model, has been questioned (Cradden 2011). These changes in industrial relations within the contemporary societies around the (developed) world are explained by the concept of neo-liberalism and a set of ideas and structural developments that can be linked to it.

At the same time, neo-liberal developments do not influence societies and industrial relation systems within all societies alike. According to Crowley 
(2004: 427), dissimilar to Western Europe, CEE countries' trade union organizations were faced with the introduction of capitalism and global pressures from an initially weak position. So it might be said that Western European unions are better equipped to deal with neo-liberal pressures and have historical legacies that support the importance of these organisations.

\section{Estonia: Capitalism without Compromise}

According to Bohle and Greskovits (2007) Estonia, Latvia and Lithuania inherited the least favourable legacies in terms of economic institutions. At the same time, these countries also felt the strongest urge to distance themselves from these legacies, which equalled Soviet domination. The prevalent discourse in the Estonian political arena since the beginning of the 1990s has been nationally-minded free market liberalism (Lagerspetz 2001). After Estonia regained its independence in 1991, its political elites pursued radical market reforms, including the elimination of state subsidies to agriculture, privatising large-scale enterprises, establishing a flat tax rate, and adopting an almost completely free trade policy (Feldmann and Sally 2002).

The radical market reforms affected population differently - creating "winners" and "losers" - that led, as there was no effective social security system in force, to several social problems (Lauristin 2003). Those agents, like trade unions, that promoted social agendas did not have any real political influence (ibid.). This has led to a situation where a market-based coordination of economic relations predominates. The industrial relations system is characterized with a low union membership, limited employers' coordination, decentralized wage bargaining, low coverage of wage agreements and limited social dialogue (Feldmann 2006). The result, as stated earlier, is that Estonia has among the lowest trade union density rates and collective agreement coverage in Europe (Visser 2013).

Although before 2009, compared to the rest of Europe, Estonia's labour legislation offered a rather strict employment protection (individual and collective dismissals were relatively heavily regulated), in reality the labour market was highly flexible. According to Eamets and Masso (2005), this resulted from the fact that there were a lot of violations of statutory regulations at the enterprise level (Eamets and Masso 2005). Since 2009, however, Estonia has had a new Employment Contracts Act that grants even more formal labour market flexibility (employers can hire and fire more easily) at the legal level. Furthermore, Estonia has relatively low social expenditures, including low unemployment benefits (with tight eligibility criteria) compared to the other OECD countries (OECD 2010). 


\section{Methodology}

The analysis is based on 15 semi-structured individual and group interviews. ${ }^{1}$ The sample that is analysed in this paper consists of 23 persons, 14 of them being the representatives of nine different sectoral level trade unions or union (con)federations, the other nine of them being the representatives of eight different employers' associations or confederations. These representatives are an important group of agents to study as they are significant in shaping the ideas and practices regarding industrial relations in Estonia.

There are two confederations of both employers and trade unions in Estonia, and the representatives of all these four central organisations were interviewed. In addition, all branch or sector level organisations had a chance of being interviewed. ${ }^{2}$ As there are only about $30 \mathrm{branch} / \mathrm{sector}$ level trade unions and about 20 employers' associations, those interviewed represent a rather wide sample. Furthermore, as these were mostly group interviews, the understandings expressed may be those perceived as more "regular" or "normal" among either employers or trade unions.

These interviews had two kind of different central themes: Either employee' participation, involvement and representation (7 interviews) or collective negotiations and collective agreements ( 8 interviews). Trade unions and employers' representatives were interviewed separately but both groups were asked the same kind of questions. Some of the central interview questions were: What should the role of collective agreements be in Estonia? What should the role of employees' representatives be? How do you feel about the extension of collective agreements? How would you describe Estonian employers' attitudes towards trade unions? Why do you think trade union membership in Estonia has dropped significantly during the last 15 years? And, what do you think will happen in the future?

I analysed the interviews using elements from a critical discourse analysis (CDA), developed by Fairclough and his colleagues. Although CDA is a method of analysis, it is also a theory (Chouliaraki and Fairclough 1999). CDA defines discourse as spoken or written language use, or other semiotic practices such as pictures or gestural communication (Fairclough 1993: 134). From the critical discourse analysis perspective, language use as a discourse is a form of social practice; viewing discourse as a social practice thus implies that it is always a socially and historically situated mode of action (Fairclough 1993: 134). Fairclough (2001: 122-123) states that the relationship between semiotic elements of social life and other elements of social practices is a dialectical relationship, that is, - semiotic elements internalise and are internalised by other elements without these different elements being reducible to each other. "Texts are both socially-structuring and socially-structured, we must examine

\footnotetext{
${ }^{1}$ The interviews were part of a bigger project commissioned by the Estonian Ministry of Social Affairs and conducted by Estonian Center for Applied Research. The project was supported by the European Social Fund.

${ }^{2}$ Except for three unions representing education, culture and theatre workers that were covered by another study.
} 
not only how texts generate meaning and thereby help to generate social structure but also how the production of meaning is itself constrained by emergent, non-semiotic features of social structure" (Fairclough et al. 2004: 27).

Although certain aspects of methods are specific to CDA, others are dependent upon the object of research. CDA includes a combination of interdiscursive analysis of texts and linguistic and other forms of semiotic analysis, but the particular nature of analysis depends upon the research object (Fairclough 2013). As my aim here is to link micro level discourses to societylevel phenomena, I present here general discursive understandings that emerged from the interviews - including argumentation that was used to support these ideas - related to trade unions in particular and labour relations in general. $^{3}$ As these interviews were conducted with the objective of examining the functioning of Estonia's collective labour relations legislation - an objective of which the interviewees were aware - it is probable that they responded according to, and in favour of, their depiction of the ideal labour relations (legislation) for them. The following research questions guided my analysis:

- What kind of discourses do different agents use when talking about labour relations in general and about trade unions in particular?

- How are these discourses legitimated?

- What discourses are dominant, what are marginalised among employers' representatives, trade unionists?

- What kind of conflicting discourses are there between employers' representatives and trade unionists?

- What kind of conflicting discourses are there within a group of social agents in similar social position, e.g., trade unionists?

\section{Discourses on Labour Relations}

This section of the paper provides an overview of the general discourses that were present in the interviews. Emphasis is given to how Estonian macro level developments can be related to micro level ideas. One of the research objectives of my study was to analyse the possible diversity of ideas and potential new/alternative understandings that may eventually lead to a change in current labour relations.

\section{Marker Forces Regulate Employment Relations. Why Interfere?}

The power of the market to regulate employment relations is strongly articulated by employers' representatives. As Cradden (2001: 50-51) argues,

${ }^{3}$ I also recognize that a shortcoming of the current analysis is that I could have described more different linguistic elements of the texts. 
according to neoliberal ideas, the compromise between capital and labour is not seen as necessary, because one sees that markets are autonomous entities that cannot be controlled by humans; so employers only adjust their reactions to the changing demands of the market. Ideas of such a kind are also prevalent in Estonian employers' representatives' argumentation. Like one employer notes:

"[During the economic boom] wages rose despite the fact that employees didn't push them up. Employers themselves raised those wages, because they were in a real competitive situation in the labour market and I doubt whether the situation is different anywhere. /.../"

Furthermore, employers also refer to the objective nature of wages and argue that people get paid based on their contribution and not their position in an enterprise.

"/../ the remuneration of a specialist can be higher than that of a middle manager. It means that these [remunerations] have gone to the direction that it depends on the market. That person, if (s)he is, it doesn't matter whether a good cleaner or a good middle manager, because if (s)he is so good that the owner of a company sees where this profit /.../ comes /.../" (Employers' representative)

These kinds of understandings are even more telling as these interviews were done soon after the economic crisis which made evident that some sectors, like real estate and construction, did not function "logically" and were rather based on a "bubble" economy.

What follows is that employers' representatives see trade unions as organisations that interfere with the "natural forces of the market" and therefore are not legitimate. Some employers' representatives depict unions as irrational actors unable to consider the opportunities companies have; so trade unions have unrealistic demands that are not in accordance with the requirements the market presents to enterprises. The notion of "rational" in employers' discourse is related to the flexibility of employment relations. Rational is the behaviour that guarantees the high flexibility of companies: As trade unions are seen as organisations decreasing flexibility, they are automatically also seen as irrational.

"You want to restructure your company /.... You know, the market always changes. /.../ and then suddenly there is the trade union, who has been /.../ friendly with you /.../ suddenly starts /.../ to work against you. /.../" (Employers' representative)

Labour market flexibility is a principle quite widely acknowledged in Estonian public discourse as necessary, in order to ensure the competitiveness of Estonia's economy. But it can also be related to what Ost (2009) calls 
structural and ideological legacies of post-communism. As flexibility is inherent to the Estonian labour relations system (Bohle and Greskovits 2007, Eamets and Masso 2005) it is a structural legacy. And, as it has become seen as the only possible way, it is also an ideological one.

\section{Trade Unions as Outdated Organisations}

The argument that trade unions are not really necessary is further supported by employers' representatives' ideas about the present social and economic organisation of society. They contended that the current world is characterised by globalisation and that employment conditions can be described as being rather good. Compared to the industrial society, they argue there are no longer any common working class interests that employees are mobile, and that people, especially Estonians, are today individualistic. This argument is in accordance with what Chiapello and Fairclough (2002) call the third spirit of capitalism that is characterised by the ideas emphasising permanent change, workers mobility, and adaptability.

It is interesting to note that employer representatives do not explicitly associate trade unions with the Soviet order; rather they associate their necessity to an industrial society. This furthermore delegitimizes the unions' position as it portrays trade unions as also obsolete in Western Europe. In fact, one employers' representative noted that employees' information and consultation rights were put in place so that there would still be some kind of role for trade unions. ${ }^{4}$

\section{Partnership Discourse}

Partnership discourse can take two different forms. Firstly, there are trade unionists and employers' representatives who stress that a partnership between trade unions and employers is a possible and useful arrangement. Among employers' representatives this discourse is rather marginal, but still present. For example, one employers' representative argued that when the aim of unions is to make the work environment and work related processes more effective - also, thus, more profitable for employers - then why should employers be against unions? But the same representative also added that when a trade union is too centred around the employees' interests, employers would probably be negatively minded towards the union.

Among trade union representatives the partnership discourse represents a dominant one. Trade unionists stress that unions just want to be listened to, and accepted by the employers; to be considered as an equal side either in a company or at the sector or societal level. They also brought out as a problem that employers have not yet acknowledged unions as their partners.

Secondly, there are employers' representatives who express the opinion that as employers and employees are partners with similar interests, trade unions are not necessary. In fact, some employers' representatives view unions

\footnotetext{
${ }^{4}$ The employers' representative probably referred to the Directive 2002/14/EC of the European Parliament and of the Council of 11 March 2002 establishing a general framework for informing and consulting employees in the European Community (Directive 2002).
} 
as even harmful in damaging a generally harmonious employee-employer relationship. Borrowing from Fox (1966), those employers' representatives express a unitary managerial ideology. This unitary view calls the necessity of unions into question, seeing them perhaps only useful when there are in really bad employment conditions. As one of employers' representative stated:

"There are probably some sectors /.../ where there really is a necessity [for trade unions]. Mutual interests are so conflicting /....."

The broader notion, however, that trade unions may be seen as organisations that promote industrial democracy (Fox 1966) is ignored.

\section{Neoliberal yet Still Necessary}

Besides being oriented towards a partnership with employers, trade unionists also express a general orientation towards the market. This means that, dissimilar to employers' representatives - who depict unions as irrational organisations, not taking into account what happens in the market - trade unionists themselves consider unions as very "rational" actors who consider what employers can afford - including analysing the economic situation before making their demands. They even noted that during the crisis several trade unions agreed to postpone wage rise or even promised to lower the wages for a period of time.

Hyman (2001) distinguishes labour movements in Western Europe as being mainly oriented according to the class and market; market and society; or society and class. Based on these interviews, it can be concluded that Estonia's unions are primarily oriented towards the market and society, with the class dimension being largely missing. This is nicely represented in one trade unionists quote:

\section{"/../ first we have to look that the demands of both employers and employees would be so-called balanced. Possibilities and then so- called needs. /.../ so that the social justice would be guaranteed to employees and employer would get better working conditions, more valuable jobs and also just competition. /.../ And the society would then win sustainable economic development. /.../"}

Despite being somewhat involved in a neoliberal discourse trade unionists still see unions as highly necessary organisations and would prefer to perform a wider range of functions than they do currently. Mostly they do not emphasise that their role should be to demand higher wages, rather they want to assure that employees would be in a more equal position. They want to be partners who negotiate, not demand.

As obstacles that prevent performing a wider range of functions trade unionists perceive, for example, the general view about unions that they are organisations belonging to a previous political order. But trade unionists also note that a lot of people do not know the roles unions currently have or could 
have. Finally, unionists also feel that some employers and politicians are hostile towards unions.

\section{Micro Level Discourses in a Societal Context}

Estonia represents a rather radical form of a neoliberal capitalism (Bohle and Greskovits 2007: 2012). Although discourses are related to already present societal structures, including power relations, they also have the potential to produce social change (Fairclough 1993). The current analysis gives little evidence that any big changes can soon be expected in the researched area. Both employers' representatives and trade unionists argue within a neoliberal logic. These interviews do not indicate that there are any radically opposing discourses within one group. Surely, trade unionists' and employer representatives' understandings and argumentation differ. The former group legitimates the unions' role by arguing for the need to be an equal partner with the employers. The latter group questions whether trade unions should have any role in a contemporary society at all.

From the perspective of trade unionists, the answer to the question heading of this paper - "Who protects workers in a neoliberal state?" - is: Unions try to fill this role, as long as employees' wishes are not "unreasonable" and are consistent with the possibilities the market offers. From the standpoint of employers' representatives, the answer to the question is that there is no need for protection at all, at least of a collective kind.

Although I analysed the situation in Estonia, the results might have wider implications. Baccaro and Howell (2011) argue convincingly that industrial relations in advanced capitalist countries are experiencing a common neoliberal transformation. If correct, trade unions all over the world might experience the same kind of issues (e.g. the problem with legitimacy) as expressed by Estonia's unionists. At the same time, we should keep in mind that the actions of employers play out against existing local practices and beliefs. Sippola (2009), for example, has found that Finnish employers who bring their business to Estonia (or other Baltic states) do not bring with them their home country management style. Rather, they use the opportunity to operate in a more liberal labour market situation where there is no "urgent need" to acknowledge the trade unions' wishes (even if union exists in a company). In this instance, it may be hypothesised that employers' arguments about the need not to have collective representation for employees is similar to that expressed by employers analysed in this paper.

\section{Acknowledgments}

This research was supported by the Estonian Research Council grant PUT106, and European Social Fund's Doctoral Studies and Internationalisation Programme DoRa, which is carried out by Foundation Archimedes. I am 
thankful for Estonian Center for Applied Research CentAR for providing me access to interviews analysed in this paper.

\section{References}

Baccaro L, Howell C (2011) A Common Neoliberal Trajectory: The Transformation of Industrial Relations in Advanced Capitalism. Politics and Society 39(4): 52163.

Bohle D, Greskovits B (2004) Capital, Labor, and the Prospects of the European Social Model in the East. Central and Eastern Europe Working Paper 58. Cambridge: Minda de Gunzburg Center for European Studies at Harvard University.

Bohle D, Greskovits B (2007) Neoliberalism, Embedded Neoliberalism, and Corporatism: Towards Transnational Capitalism in Central-Eastern Europe. West European Politics 30(3): 443-66.

Bohle D, Greskovits B (2012) Capitalist diversity on Europe's periphery. Ithaca: Cornell University Press.

Calmfors L, Booth A, Burda M, Checchi D, Naylor R, Visser J (2001) Part I The Future of Collective Bargaining in Europe. In Boeri T, Brugiavini A, Calmfors L, (Eds) The Role of Unions in the Twenty-First Century: A Report for the Fondazione Rodolfo Debenedetti, 1-151. Oxford: Oxford University Press.

Chiapello E, Fairclough N (2002) Understanding the new management ideology: a transdisciplinary contribution from critical discourse analysis and new sociology of capitalism. Discourse and Society 13(2): 185-208.

Chouliaraki L, Fairclough N (1999) Discourse in late modernity: Rethinking critical discourse analysis. Edinburgh: Edinburgh University Press.

Cradden C (2011) Understanding the past to change the present: the social compromise, the corporate theory of society and the future shape of industrial relations. In Serrano M, Xhafa E, Fichter M (Eds) Trade unions and the global crisis: Labour's visions, strategies and responses, 49-62. Geneva: International Labour Organization.

Crowley S (2004) Explaining Labor Weakness in Post-Communist Europe: Historical Legacies and Comparative Perspective. East European Politics and Societies 18(3): 394-429.

Eamets R, Masso J (2005) The Paradox of the Baltic States: Labour Market Flexibility but Protected Workers? European Journal of Industrial Relations 11(1): 71-90.

Directive (2002) Directive 2002/14/EC of the European Parliament and the Council. Official Journal of the European Communities. Retrieved from http://bit.ly/1yV9TkB. [Accessed 11 February 2015].

Fairclough N (1993) Critical discourse analysis and the marketization of public discourse: The universities. Discourse and Society 4(2): 133-68.

Fairclough N (2001) Critical discourse analysis as a method in social scientific research. In Wodak R, Meyer M (Eds) Methods in critical discourse analysis, 121-38. London: Sage.

Fairclough N (2013) Critical discourse analysis: The critical study of language. New York: Routledge.

Fairclough N, Jessop J, Sayer A (2004) Critical realism and semiosis. In Joseph J, Roberts JM, (Eds) Realism, Discourse and Deconstruction, 23-42. London and New York: Routledge. 
Feldmann M (2006) Emerging Varieties of Capitalism in Transition Countries: Industrial Relations and Wage Bargaining in Estonia and Slovenia. Comparative Political Studies 39(7): 829-54.

Feldmann M, Sally R (2002) From the Soviet Union to the European Union: Estonian Trade Policy, 1991-2000. The world economy 25(1): 79-106.

Frege K (2001) Union weakness and postcommunist identities in Eastern Europe: evidence from the Hungarian clothing industry. Industrial Relations Journal 32(4): 295-312.

Fox A (1966) Managerial ideology and labour relations. British Journal of Industrial Relations 4(1-3): 366-378.

Hyman R (2001) Understanding European Trade Unionism: Between Market, Class and Society. London: Sage.

Kubicek P (2002) Civil Society, Trade Unions and Post-Soviet Democratisation: Evidence from Russia and Ukraine. Europe-Asia Studies 54(4): 603-24.

Lagerspetz M (2001) Consolidation as hegemonization: The case of Estonia. Journal of Baltic Studies 32(4): 402-20.

Lauristin M (2003) Social Contradictions Shadowing Estonia's "Success Story". Demokratizatsiya 11(4): 601-16.

Mrozowicki A, Pulignano V, Hootegem GV (2010) Worker agency and trade union renewal: the case of Poland. Work, Employment and Society 24(2): 221-40.

OECD (2010) OECD Reviews of Labour Market and Social Policies: Estonia 2010. Organisation of Economic Co-operation and Development. Retrieved from http://bit.ly/1HS8nXL. [Accessed 10 February 2015].

Ost D (2000) Illusory Corporatism in Eastern Europe: Neoliberal Tripartism and Postcommunist Class Identities. Politics and Society 28(4): 503-30.

Ost D (2009) The Consequences of Postcommunism: Trade Unions in Eastern Europe's Future. East European Politics and Societie, 23(1): 13-33.

Sipplola M (2009) The two faces of Nordic management? Nordic firms and their employee relations in the Baltic States. The International Journal of Human Resource Management 20(9): 1929-44.

Standing G (2011) The Precariat: The New Dangerous Class. London, New York: Bloomsbury Academic.

Turner L (2005) From Transformation to Revitalization: A New Research Agenda for a Contested Global Economy. Work and occupations 32(4): 383-99.

Visser J (2013) ICTWSS: Database on Institutional Characteristics of Trade Unions, Wage Setting, State Intervention and Social Pacts in 34 countries between 1960 and 2007, Amsterdam Institute for Advanced Labour Studies, University of Amsterdam, Ver. 4. Retrieved from http://www.uva-aias.net/208. [Accessed 10 February 2015].

Woolfson C, Kallaste E (2011) 'Illusory Corporatism "Mark 2"' in the Baltic States. Warsaw Forum of Economic Sociology 2(3): 51-72. 